\title{
Association between glucocorticoids treatment and viral clearance delay in patients with COVID-19: a systematic review and meta-analysis
}

Jianbo $\mathrm{Li}^{1+}$, Xuelian Liao ${ }^{1+}$, Yue Zhou' ${ }^{1}$ Luping Wang ${ }^{1}$, Hang Yang ${ }^{1}$, Wei Zhang ${ }^{2}$, Zhongwei Zhang ${ }^{1 *}$ and Yan Kang ${ }^{1 *}$ (D)

\begin{abstract}
Background: Evidence of glucocorticoids on viral clearance delay of COVID-19 patients is not clear.

Methods: In this systematic review and meta-analysis, we searched for studies on Medline, Embase, EBSCO, ScienceDirect, Web of Science, Cochrane Library, and ClinicalTrials.gov from 2019 to April 20, 2021. We mainly pooled the risk ratios (RRs) and mean difference (MD) for viral clearance delay and did subgroup analyses by the severity of illness and doses of glucocorticoids.

Results: 38 studies with a total of 9572 patients were identified. Glucocorticoids treatment was associated with delayed viral clearance in COVID-19 patients (adjusted RR 1.52, 95\% Cl 1.29 to $1.80, \mathrm{I}^{2}=52 \%$ ), based on moderatequality evidence. In subgroup analyses, risk of viral clearance delay was significant both for COVID-19 patients being mild or moderate ill (adjusted RR $1.86,95 \% \mathrm{Cl} 1.35$ to $2.57, \mathrm{I}^{2}=48 \%$ ), and for patients of being severe or critical ill (adjusted RR $1.59,95 \% \mathrm{Cl} 1.23$ to $2.07, \mathrm{I}^{2}=0 \%$ ); however, this risk significantly increased for patients taking high doses (unadjusted RR 1.85, 95\% Cl 1.08 to 3.18; MD 7.19,95\% Cl 2.78 to 11.61) or medium doses (adjusted RR 1.86, 95\% Cl 0.96 to $3.62, \mathrm{I}^{2}=45 \%$; MD 3.98, 95\% Cl 3.07 to $4.88, \mathrm{I}^{2}=4 \%$ ), rather those taking low doses (adjusted RR $1.38,95 \% \mathrm{Cl}$ 0.94 to $2.02, I^{2}=59 \% ; M D 1.46,95 \% \mathrm{Cl}-0.79$ to $\left.3.70, I^{2}=82 \%\right)$.
\end{abstract}

Conclusions: Glucocorticoids treatment delayed viral clearance in COVID-19 patients of taking high doses or medium doses, rather in those of taking low doses of glucocorticoids.

Keywords: COVID-19, Glucocorticoids treatment, Viral clearance delay

\section{Introduction}

As of early August 2021, nearly 200 million people have been confirmed with COVID-19, and more than 4 million died according to WHO official updates of global data on COVID-19 [1]. Historically, glucocorticoids were

\footnotetext{
*Correspondence: zhangzhongweihx@foxmail.com; kangyan@scu.edu.cn ${ }^{\dagger}$ Jianbo Li and Xuelian Liao contributed equally to this work

${ }^{1}$ Department of Critical Care Medicine, West China Hospital, Sichuan

University, 37 Guo Xue Xiang St, Chengdu 610041, Sichuan, China

Full list of author information is available at the end of the article
}

widely recommended to treat SARS, but this proved to be controversial. A recent large randomized controlled trial (RCT) [2] from the United Kingdom compared 2104 hospital COVID-19 patients who were given dexamethasone with those of 4321 patients who were not. Results from this large trial showed glucocorticoid treatment cut the risk of death from 40 to $28 \%$ for patients on ventilators and from 25 to $20 \%$ for patients needing oxygen. Then, a systematic review and meta-analysis [3] involving 7 RCTs also revealed a significant association between 
glucocorticoids treatment and decreased mortality in COVID-19 patients of critical illness. Although these results are encouraging, glucocorticoids theoretically delay virus removal. At present, no study has systematically assessed glucocorticoids treatment effects on viral clearance for COVID-19. Thus, we conducted this systematic review and meta-analysis to evaluate this potential effect from glucocorticoids treatment for COVID-19.

\section{Methods}

\section{Guidance and protocol}

We reported our study according to standards of the meta-analysis of observational studies in epidemiology (MOOSE) [4] and preferred reporting items for systematic reviews and meta-analyses (PRISMA) [5]. We registered our protocol for this review and meta-analysis on PROSPERO (CRD42020194225).

\section{Eligibility criteria and definitions}

We considered criteria of eligible studies as follows: participants were COVID-19 patients infected with SARS$\mathrm{CoV}-2$ confirmed through the nucleic acid test; the intervention was glucocorticoids, no matter types, and doses; the controls were COVID-19 patients receiving usual care except glucocorticoids treatment; the outcomes should involve viral clearance, no matter what kind of data was presented. Both RCTs and observational studies (including cohort studies, case-control studies, case series of more than 10 patients) were included. Viral clearance delay was defined as the opposite of SARSCoV-2 RNA shedding at any time from illness onset (different studies were based on different time frames, usually at $\geq 7$-day from illness onset) and the SARSCoV-2 RNA shedding was defined as two consecutive RNA negative with at least 24-h intervals and the date of the first negative test was defined as the day of viral RNA clearance [6-9].

\section{Literature search}

Two of the authors (JB.L. and XL.L.) conducted a literature search on several databases: Medline (Ovid), Embase (Ovid), EBSCO, ScienceDirect, Web of Science (All database), Cochrane Library, and ClinicalTrials.gov from 2019 to April 20, 2021. Also, we reviewed reference lists of identified studies, systematic reviews, and review articles on the same topic. Language or publication status was not restricted. Additional file 1: Table S1 showed the details of the search strategy.

\section{Study selection}

After duplicates were removed, the title and abstract of each item were browsed to screen studies with eligible participants and intervention by two independent groups of four authors (H.Y. and W.Z.; Y.Z. and LP.W.). Further screening was conducted to determine whether the item met the rest eligibility criteria. The time, hospital, and number of patients involved in each study were also examined, and studies with highly repetitive cohort and no additional subgroup information would be excluded. Disagreements were resolved by consensus, and if necessary, consultation with a third author (ZW.Z.).

\section{Data collection process}

Data from included studies were extracted into standard collection forms and information tables for quality assessment were created. The quantile estimation method was applied to estimate the sample mean and standard deviation if a study presented summary statistics as median, first and third quartiles, and sample size. Note that if the study reported a hazard ratio (HR) of SARS-CoV-2 RNA shedding [10-13] rather than viral clearance delay, then an $\mathrm{HR}$ of viral clearance delay was obtained by taking the reciprocal of the HR i.e.1/ HR and associated confidence interval (CI).

\section{Assessment of risk of bias}

The Newcastle-Ottawa-Scale (NOS) [14] for observational studies and using the Revised Cochrane riskof-bias tool for randomized trials ( $\operatorname{RoB} 2)$ were used to assess the risk of bias by two independent groups of four authors (H.Y. and W.Z.; Y.Z. and LP.W.). Each domain of NOS was composed of 2 to 4 items of criteria, and each criterion was scored in the form of stars. A total score of 8 or 9 was assessed as low risk of bias, 6 or 7 as some concerns, and $\leq 5$ as high risk. Each domain of RoB 2 was assessed as low risk, some concerns, or a high risk of bias. The study's overall risk of bias was determined by the highest risk of bias for any criteria. Disagreements were resolved by consensus, and if necessary, consultation with a third author (ZW.Z.).

\section{Data synthesis}

Statistical analyses were performed using the meta package in $\mathrm{R}$ (version 4.0.1; The R Project for Statistical Computing). We mainly used risk ratios (RRs) and their associated $95 \% \mathrm{CI}$ to assess outcomes, as well as a prediction interval (PI) for the effect of future studies based on the present [15]. Adjusted RRs and unadjusted RRs (including frequency counts in the $2 \times 2$ table for binary data) were separately pooled. We equivalently transformed HRs [16] and odds ratios (ORs) [17] into RRs and log-transform these effect sizes as well as their standard errors first before they were pooled. If provided, we also pooled mean difference (MD) for continuous data. We used random-effects models to pool data. The $\mathrm{I}^{2}$ test was used to examine heterogeneity and 
$\mathrm{I}^{2} \geq 50 \%$ was considered as significant heterogeneity. A 2 -tailed $P$ value of less than 0.05 was statistically significant. Funnel plots and the Egger test were adopted to assess the publication bias of the main results.

\section{Subgroup analysis}

We planned several subgroup analyses according to the following variables: (1) severity of illness (mild or moderate and severe or critical); (2) doses (equivalent methylprednisolone) of glucocorticoids (low dose $[0.5-1 \mathrm{mg} / \mathrm{kg} /$ day or $<80 \mathrm{mg} /$ day], medium dose [1-2 $\mathrm{mg} / \mathrm{kg} /$ day or $80-200 \mathrm{mg} /$ day], and high dose [>2 mg/kg/day or $>200 \mathrm{mg} /$ day]). The severity of illness was reported by the studies following Chinese interim guidelines for diagnosis and treatment for COVID-19 patients (version 7.0) [18, 19].

\section{Sensitivity analysis}

We conducted sensitivity analyses on main results from adjusted RRs by (1) influence analyses [20] based on leave-one-out-method (2) excluding studies of case-control design, (3) excluding studies of retrospective cohort design, (4) excluding studies with the non-low risk of bias.

\section{Results}

\section{Eligible studies and study characteristics}

Of the 15,357 records, 38 studies [6-13, 21-50] involving a total of 9572 patients were included in both qualitative and quantitative synthesis, and another study [51] was included only for qualitative synthesis (Fig. 1). Table 1 showed the characteristics of the included 39 studies. These studies, with a size from 31 to 966 and a median age from 39 to 66, comprised 1 RCT, 13 case-control studies, and 25 retrospective cohort studies. One of the

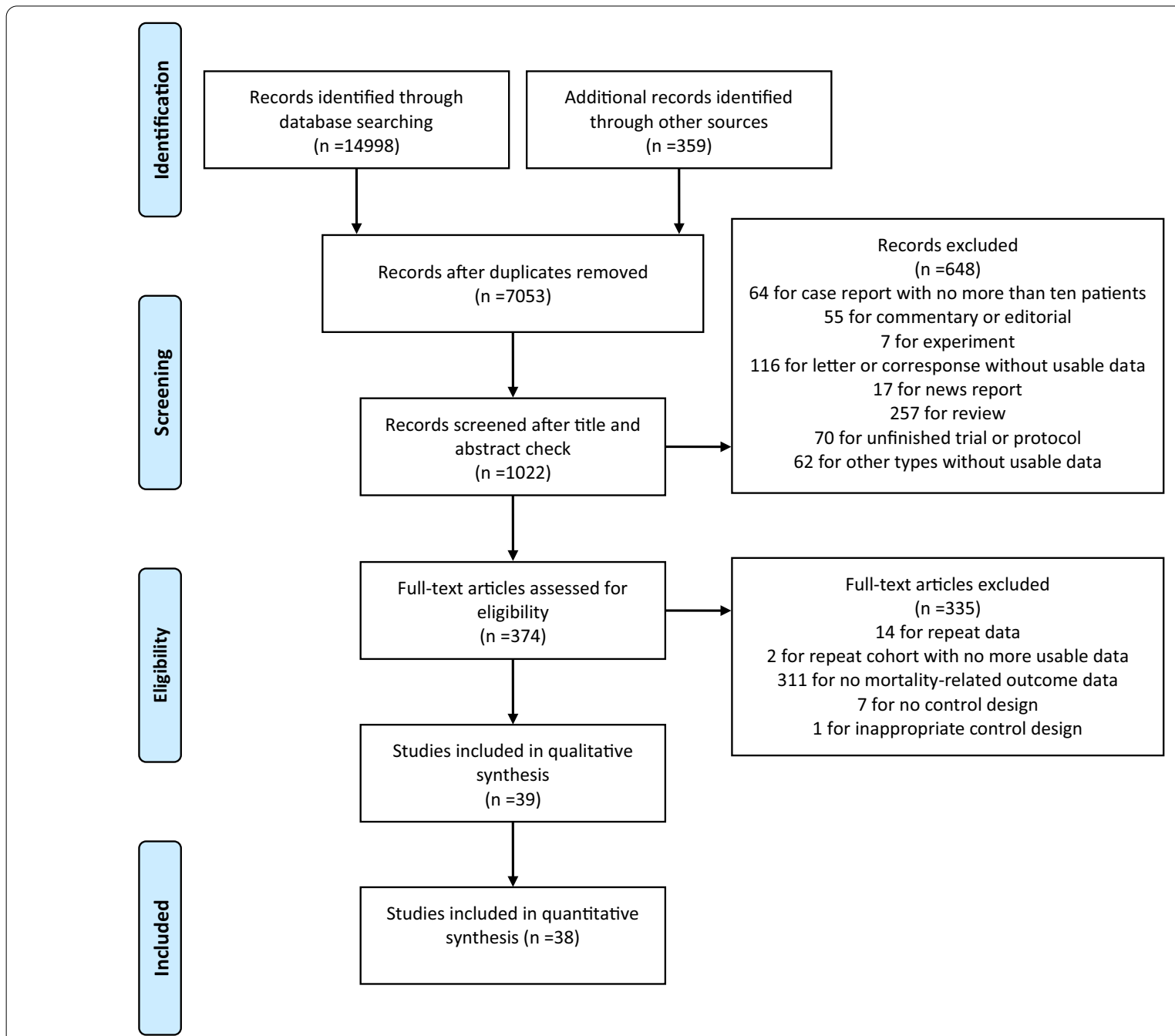

Fig. 1 Preferred Reporting Items for Systematic Reviews and Meta-Analyses (PRISMA) for the Article Selection Process 
Table1 Characteristics of Included Studies

\begin{tabular}{|c|c|c|c|c|c|c|c|c|c|}
\hline Author, year & Country & Design & Size & $\begin{array}{l}\text { Age (Median/ } \\
\text { median } \\
\text { range, years) }\end{array}$ & $\begin{array}{l}\text { Glucocorticoids } \\
\text { dose } \\
\text { (Equivalent of } \\
\text { MP) }\end{array}$ & $\begin{array}{l}\text { Glucocorticoids } \\
\text { type }\end{array}$ & $\begin{array}{l}\text { Treatment } \\
\text { timing (From } \\
\text { illness onset, } \\
\text { median days) }\end{array}$ & $\begin{array}{l}\text { Treatment } \\
\text { duration } \\
\text { (Median/ } \\
\text { range, days) }\end{array}$ & $\begin{array}{l}\text { Time frame } \\
\text { of viral } \\
\text { clearance delay } \\
\text { (Follow-up) }\end{array}$ \\
\hline $\begin{array}{l}\text { Cao and Zhu } \\
\text { et al. [20] }\end{array}$ & China & $\mathrm{CC}$ & 87 & NA & NA & NA & NA & NA & 14-, 10-day \\
\hline $\begin{array}{l}\text { Chang and } \\
\text { Zhao et al. [21] }\end{array}$ & China & $\mathrm{CC}$ & 67 & $14-59$ & NA & NA & NA & NA & 16-day ( 16 days) \\
\hline $\begin{array}{l}\text { Chen and Li } \\
\text { et al. [23] }\end{array}$ & China & $\mathrm{RC}$ & 70 & $47-64$ & $\begin{array}{l}0.5-1 \mathrm{mg} / \mathrm{kg} / \mathrm{d} \\
\text { (low dose); } \\
1-2 \mathrm{mg} / \mathrm{kg} / \mathrm{d} \\
\text { (medium-dose); } \\
200-400 \mathrm{mg} / \mathrm{d} \\
\text { (high-dose) }\end{array}$ & NA & NA & NA & NA \\
\hline $\begin{array}{l}\text { Chen and } \\
\text { Song et al. [22] }\end{array}$ & China & $\mathrm{RC}$ & 371 & $63-65$ & Mean $49.5 \mathrm{mg} / \mathrm{d}$ & $\mathrm{DM}, \mathrm{MP}, \mathrm{PN}$ & Mean 14.1 & Mean 9.1 & NA \\
\hline $\begin{array}{l}\text { Chen and Zhu } \\
\text { et al. [9] }\end{array}$ & China & RC & 267 & 49 & NA & NA & NA & NA & 45-day \\
\hline $\begin{array}{l}\text { Cogliati-Dezza } \\
\text { and Oliva et al. } \\
\text { [5] }\end{array}$ & Italy & $\mathrm{CC}$ & 179 & 62 & NA & $\mathrm{DM}, \mathrm{MP}$ & NA & NA & 14-day \\
\hline $\begin{array}{l}\text { Ding and Feng } \\
\text { et al. [24] }\end{array}$ & China & $\mathrm{RC}$ & 82 & 49 & NA & NA & NA & NA & NA \\
\hline $\begin{array}{l}\text { Fang and Mei } \\
\text { et al. [25] }\end{array}$ & China & $\mathrm{RC}$ & 55 & $39.9-60.6$ & $\begin{array}{l}\text { Median } \\
38 \mathrm{mg} / \mathrm{d} \text { in } \\
\text { general patients; } \\
40 \mathrm{mg} / \mathrm{d} \text { in } \\
\text { severe patients }\end{array}$ & MP & NA & $\begin{array}{l}7 \text { in general } \\
\text { patients; } 4.5 \\
\text { in severe } \\
\text { patients }\end{array}$ & NA \\
\hline $\begin{array}{l}\text { Feng and } \mathrm{Li} \\
\text { et al. [6] }\end{array}$ & China & CC & 564 & 47 & NA & NA & NA & NA & NA (50 days) \\
\hline $\begin{array}{l}\text { Fu and Luo } \\
\text { et al. [26] }\end{array}$ & China & $\mathrm{RC}$ & 33 & $41-65$ & $1 \mathrm{mg} / \mathrm{kg} / \mathrm{d}$ & MP & NA & NA & NA ( $\geq 22$ days) \\
\hline $\begin{array}{l}\text { Gong and } \\
\text { Guan et al. [27] }\end{array}$ & China & $\mathrm{RC}$ & 34 & $33.8-38.2$ & $1-2 \mathrm{mg} / \mathrm{kg} / \mathrm{d}$ & MP & NA & $5-10$ & NA \\
\hline $\begin{array}{l}\text { Hu and Li et al. } \\
{[10]}\end{array}$ & China & $\mathrm{CC}$ & 206 & Mean 53.7 & $\begin{array}{l}40 \mathrm{mg} / \mathrm{d} \text { (low- } \\
\text { dose); } 80 \mathrm{mg} / \mathrm{d} \\
\text { (high-dose) }\end{array}$ & MP & NA & NA & 30-day \\
\hline $\begin{array}{l}\text { Hu and Yin } \\
\text { et al. [28] }\end{array}$ & China & $\mathrm{CC}$ & 183 & 49 & $\begin{array}{l}\text { Median } \\
43.3 \mathrm{mg} / \mathrm{d}\end{array}$ & NA & NA & 4 & 20-day \\
\hline $\begin{array}{l}\text { Huang and } \\
\text { Zhu et al. [11] }\end{array}$ & China & $\mathrm{RC}$ & 309 & 45 & $40-160 \mathrm{mg} / \mathrm{d}$ & MP & NA & NA & NA (40 days) \\
\hline $\begin{array}{l}\text { Jeronimo and } \\
\text { Farias et al. [29] }\end{array}$ & Brazil & $\mathrm{RCT}$ & 283 & Mean 55 & 1 mg/kg/day & MP & NA & 5 & 5-, 7-day \\
\hline $\begin{array}{l}\text { Ji and Zhang } \\
\text { et al. [30] }\end{array}$ & China & $\mathrm{RC}$ & 490 & 61 & $1-2 \mathrm{mg} / \mathrm{kg} /$ day & $\mathrm{DM}, \mathrm{MP}, \mathrm{PN}$ & NA & $3-5$ & 14-, 28-day \\
\hline $\begin{array}{l}\text { Li and Cao } \\
\text { et al. [31] }\end{array}$ & China & CC & 66 & 47.5 & NA & MP & NA & NA & 11-day \\
\hline $\begin{array}{l}\text { Li and Li et al. } \\
\text { [12] }\end{array}$ & China & $\mathrm{RC}$ & 475 & 42 & 20 or $40 \mathrm{mg} / \mathrm{d}$ & MP, PS & $\begin{array}{l}2 \text { (from admis- } \\
\text { sion) }\end{array}$ & NA & NA (50 days) \\
\hline $\begin{array}{l}\text { Li and Meng } \\
\text { et al. [32] }\end{array}$ & China & RC & 294 & 66 & Median $40 \mathrm{mg} / \mathrm{d}$ & $\mathrm{DM}, \mathrm{MP}, \mathrm{HC}, \mathrm{PN}$ & $\begin{array}{l}0 \text { (from ICU } \\
\text { admission) }\end{array}$ & 9 & NA (90 days) \\
\hline $\begin{array}{l}\text { Liang and } \\
\text { Chen et al. [33] }\end{array}$ & China & $\mathrm{RC}$ & 966 & 60 & $\leq 1-2 \mathrm{mg} / \mathrm{kg} / \mathrm{d}$ & MP & NA & $>3$ & $\mathrm{NA}$ ( $\geq 50$ days) \\
\hline $\begin{array}{l}\text { Liu and Li et al. } \\
\text { [35] }\end{array}$ & China & $\mathrm{RC}$ & 646 & 57 & Median 80 mg/d & $\mathrm{DM}, \mathrm{MP}, \mathrm{PN}$ & 13 & NA & NA \\
\hline $\begin{array}{l}\text { Liu and Zhang } \\
\text { et al. [34] }\end{array}$ & China & $\mathrm{RC}$ & 774 & 64 & Median $40 \mathrm{mg} / \mathrm{d}$ & MP, PS & $\begin{array}{l}1 \text { (from admis- } \\
\text { sion) }\end{array}$ & 6 & 30-day \\
\hline $\begin{array}{l}\text { Lu and Liu } \\
\text { et al. [36] }\end{array}$ & China & $\mathrm{RC}$ & 374 & $47-51$ & $\begin{array}{l}\text { Median } 220 \mathrm{mg} \\
\text { (cumulative } \\
\text { dose) }\end{array}$ & NA & $\begin{array}{l}\leq 5 \text { (from } \\
\text { admission) }\end{array}$ & 4 & $\mathrm{NA}$ ( $\geq 40$ days) \\
\hline
\end{tabular}


Table1 (continued)

\begin{tabular}{|c|c|c|c|c|c|c|c|c|c|}
\hline Author, year & Country & Design & Size & $\begin{array}{l}\text { Age (Median/ } \\
\text { median } \\
\text { range, years) }\end{array}$ & $\begin{array}{l}\text { Glucocorticoids } \\
\text { dose } \\
\text { (Equivalent of } \\
\text { MP) }\end{array}$ & $\begin{array}{l}\text { Glucocorticoids } \\
\text { type }\end{array}$ & $\begin{array}{l}\text { Treatment } \\
\text { timing (From } \\
\text { illness onset, } \\
\text { median days) }\end{array}$ & $\begin{array}{l}\text { Treatment } \\
\text { duration } \\
\text { (Median/ } \\
\text { range, days) }\end{array}$ & $\begin{array}{l}\text { Time frame } \\
\text { of viral } \\
\text { clearance delay } \\
\text { (Follow-up) }\end{array}$ \\
\hline $\begin{array}{l}\text { Ma and Qi } \\
\text { et al. [37] }\end{array}$ & China & $\mathrm{RC}$ & 72 & Mean 60 & 40 or $80 \mathrm{mg} / \mathrm{d}$ & MP & NA & 3 & NA \\
\hline $\begin{array}{l}\text { Ma and Zeng } \\
\text { et al. [38] }\end{array}$ & China & $\mathrm{RC}$ & 368 & Mean 46.2 & $\begin{array}{l}\text { Median } \\
56.6 \mathrm{mg} / \mathrm{d}\end{array}$ & MP, PS & 9 & 5 & NA \\
\hline $\begin{array}{l}\text { Masia and } \\
\text { Fernandez- } \\
\text { Gonzalez et al. } \\
\text { [39] }\end{array}$ & Spain & $\mathrm{RC}$ & 77 & $63.5-71$ & $250-500 \mathrm{mg} / \mathrm{d}$ & MP & NA & 3 & NA \\
\hline $\begin{array}{l}\text { Ni and Ding } \\
\text { et al. [40] }\end{array}$ & China & $\mathrm{RC}$ & 72 & $46-52$ & $\begin{array}{l}0.75-1.5 \mathrm{mg} / \\
\mathrm{kg} / \mathrm{d}\end{array}$ & MP & NA & NA & NA \\
\hline $\begin{array}{l}\text { Qi and Yang } \\
\text { et al. [41] }\end{array}$ & China & $\mathrm{CC}$ & 147 & 42 & NA & NA & NA & NA & 17-day \\
\hline $\begin{array}{l}\text { Shi and Wu } \\
\text { et al. [42] }\end{array}$ & China & $C C$ & 99 & 54 & Median $60 \mathrm{mg} / \mathrm{d}$ & NA & 8 & NA & 28-day \\
\hline $\begin{array}{l}\text { Shu and He } \\
\text { et al. [43] }\end{array}$ & China & $\mathrm{CC}$ & 83 & 43 & NA & NA & NA & NA & 16-day \\
\hline $\begin{array}{l}\text { Spagnuolo } \\
\text { and Guffanti } \\
\text { et al. [44] }\end{array}$ & Italy & $\mathrm{RC}$ & 149 & 63.5 & $\begin{array}{l}\text { Median of } \\
0.38 \mathrm{mg} / \mathrm{kg} / \mathrm{d}\end{array}$ & $\mathrm{DM}, \mathrm{MP}, \mathrm{PN}$ & $\begin{array}{l}1 \text { (from admis- } \\
\text { sion) }\end{array}$ & 9 & $\begin{array}{l}14-, 14 \text { to } 28-, 28 \\
\text { to } 40-,>40-\text { day }\end{array}$ \\
\hline $\begin{array}{l}\text { Wu and Hou } \\
\text { et al. [45] }\end{array}$ & China & $\mathrm{RC}$ & 382 & Mean 60.7 & NA & $\mathrm{DM}, \mathrm{MP}, \mathrm{PN}$ & NA & NA & NA \\
\hline $\begin{array}{l}\text { Xia and Xu } \\
\text { et al. [46] }\end{array}$ & China & $\mathrm{RC}$ & 49 & NA & $\begin{array}{l}0.75-1.5 \mathrm{mg} / \\
\mathrm{kg} / \mathrm{d}\end{array}$ & MP & $\begin{array}{l}\leq 3 \text { (from } \\
\text { admission) }\end{array}$ & NA & $N A$ ( $\geq 10$ days) \\
\hline $\begin{array}{l}\text { Xiong and Jin } \\
\text { et al. [50] }\end{array}$ & China & $\mathrm{RC}$ & 66 & Mean 62 & $\begin{array}{l}\text { Median } 400 \text { mg } \\
\text { (cumulative } \\
\text { dose) }\end{array}$ & NA & 9 & NA & $N A(\geq 30$ days) \\
\hline $\begin{array}{l}\text { Xu and Chen } \\
\text { et al. [47] }\end{array}$ & China & $\mathrm{CC}$ & 113 & 52 & $0.5-1 \mathrm{mg} / \mathrm{kg} / \mathrm{d}$ & MP & NA & NA & 15-day \\
\hline $\begin{array}{l}\text { Yan and Liu } \\
\text { et al. [7] }\end{array}$ & China & CC & 120 & 52 & NA & NA & NA & NA & 23-day \\
\hline $\begin{array}{l}\text { Yuan and Xu } \\
\text { et al. [8] }\end{array}$ & China & $\mathrm{RC}$ & 132 & $43.7-52$ & $\begin{array}{l}\text { Median } \\
52.2 \mathrm{mg} / \mathrm{d}\end{array}$ & MP & 8.3 & 10.8 & NA \\
\hline $\begin{array}{l}\text { Zha and Li } \\
\text { et al. [48] }\end{array}$ & China & $\mathrm{RC}$ & 31 & 39 & $40-80 \mathrm{mg} / \mathrm{d}$ & MP & NA & NA & NA \\
\hline $\begin{array}{l}\text { Zuo and Liu } \\
\text { et al.. [49] }\end{array}$ & China & $\mathrm{CC}$ & 181 & Mean 44.3 & NA & NA & NA & NA & 21-day \\
\hline
\end{tabular}

$\mathrm{CC}$, case control; RC, retrospective cohort; RCT, randomized controlled trial; DM, dexamethasone; MP, methylprednisolone; PN, prednisone; PS, prednisolone; HC, hydrocortisone; NA, not available

studies came from Brazil, one from Spain, two from Italy, and the rest from China. Most studies used a low or medium dose of glucocorticoids, and a few studies $[24,40]$ reported the use of high-dose glucocorticoids. Methylprednisolone was the most common type, followed by dexamethasone, prednisone and prednisolone, and finally hydrocortisone. The median days for glucocorticoids treatment from illness onset ranged from 8 to 13 days and the median duration of treatment from 3 to 10.8 days. The studies reported different time frames of viral clearance delay, between 5- and 45-day, and the longest reported follow-up was 90 days.
Additional files 2, 3, 4: Tables S2-S4 showed the risk bias of the included studies, and Additional file 5: Tables S5 listed adjusted factors in each included study. 12 studies were considered as low risk, 25 as some concerns, and 2 as high risk. The average score of total risk bias for case-control studies was 6.9 and the average score for retrospective cohort studies was 7.0. The only RCT was assessed as the trial with the risk bias of some concerns, due to its deviations from intended interventions.

\section{Risk of viral clearance delay}

A total of 23 studies were involved to calculate RRs for risk of viral clearance delay in COVID-19 patients who 
received glucocorticoids treatment, of which the longest follow-up was 50 days. The overall unadjusted RR (1.38, $95 \%$ CI 1.18 to $1.61, \mathrm{I}^{2}=98 \%$, PI 0.62 to 3.06$)$ and adjusted RR (1.52, 95\% CI 1.29 to $1.80, \mathrm{I}^{2}=52 \%$, PI 0.86 to 2.70) (Fig. 2) revealed an association between glucocorticoids treatment and increased risk of viral clearance delay in COVID-19 patients. There were 20 studies reporting the time of viral shedding. The pooled MD of days for SARS-CoV-2 RNA shedding from illness onset $\left(1.84,95 \%\right.$ CI 0.73 to $2.96, \mathrm{I}^{2}=83 \%$, PI -3.27 to 6.96$)$ (Fig. 2) also confirmed the delayed viral clearance in glucocorticoids treatment patients, compared to patients receiving non-glucocorticoids treatment.

Influence analyses found no study with an excessive influence on the overall results and the sensitivity analysis using the leave-one-out method confirmed the stability of the estimated adjusted RR (Additional file 6: Figure S1). The other sensitivity analyses also showed a similar result to that from the main analysis (Additional files 7 , 8, 9: Figure S2-S4).

\section{Subgroup analysis}

Subgroup analysis revealed that the risk of viral clearance delay was significantly higher in glucocorticoidstreated COVID-19 patients of being mild or moderate (adjusted RR 1.86, 95\% CI 1.35 to $2.57, \mathrm{I}^{2}=48 \%$; MD $1.67,95 \%$ CI 0.18 to $3.61, \mathrm{I}^{2}=24 \%$ ), but not so high for patients of being severe or critical (adjusted RR 1.59, 95\% CI 1.23 to $2.07, \mathrm{I}^{2}=0 \%$; MD $0.95,95 \%$ CI -2.71 to 2.51 , $\mathrm{I}^{2}=77 \%$ ) (Fig. 3). When comparing the risk of viral clearance delay between a low dose, a medium dose, and a high dose of glucocorticoids, subgroup analysis showed that a high dose (unadjusted RR 1.85, 95\% CI 1.08 to 3.18; MD 7.19, 95\% CI 2.78 to 11.61 ) or a medium dose (unadjusted RR 1.28, 95\% CI 1.07 to $1.53, \mathrm{I}^{2}=99 \%$; adjusted RR 1.86, $95 \%$ CI 0.96 to $3.62, \mathrm{I}^{2}=45 \%$; MD $3.98,95 \%$ CI 3.07 to $4.88, \mathrm{I}^{2}=4 \%$ ) of glucocorticoids increased the risk of viral clearance delay, but not for a low dose (unadjusted RR $1.20,95 \%$ CI 0.99 to $1.46, I^{2}=98 \%$; adjusted RR 1.38 , 95\% CI 0.94 to $2.02, \mathrm{I}^{2}=59 \%$; MD $1.46,95 \%$ CI -0.79 to $3.70, \mathrm{I}^{2}=82 \%$ ) (Fig. 4). In our qualitative synthesis, a few studies [33, 45, 47,51] investigated the effect of use timing of glucocorticoids on the viral shedding, the results indicated late use rather than early use of glucocorticoids was significantly associated with a high risk of viral clearance delay.

\section{Publication bias}

There was a significant asymmetry on the report of unadjusted RRs (Additional file 10: Figure S5), however, funnel plot analysis showed no asymmetry on the report of adjusted RRs and MDs (Additional files 11, 12: Figure
S6-S7), and the Egger test detected no significant smallstudy effects.

\section{Discussion}

In this meta-analysis of 38 studies (at moderate risk of bias involving 9572 patients), glucocorticoids treatment was significantly associated with an increased risk of viral clearance delay in COVID-19 patients. Evidence indicated a high or medium-dose but not a low dose of glucocorticoids, could substantially lead to viral clearance delay. Though only one RCT was included, however, adjusted data from observational studies and low heterogeneity of pooled data ensured the power of conclusions.

\section{Principal findings and comparison with other studies}

As of writing this manuscript (early May 2021), no metaanalysis has quantitatively examined the use of glucocorticoids in patients with COVID-19 regarding viral clearance delay. Yousefifard et al.. conducted a meta-analysis on efficacy and safety of glucocorticoids on the management of COVID-19, SARS, and MERS, in which the search was conducted at the end of March 2020, and only 5 studies on COVID-19 were included [52]. Not enough data allowed that meta-analysis to quantitatively analyze glucocorticoids on the effect of viral clearance delay and the conclusion that corticosteroids administration would not be effective in shortening viral clearance time was only supported by qualitative analysis of evidence from a case report of nine COVID-19 patients, although it did not conflict with our conclusion in essence. Most trials of glucocorticoids suspended enrollment after the RECOVERY trial which was the globally largest one and drew an encouraging conclusion of reduction in mortality of COVID-19. However, as one kind of immunosuppressant, glucocorticoids' detrimental effect-one of the most important side effects, i.e. viral clearance delay-had not been further investigated in these trials. Thus, information about its impact on the humoral immune response against the virus is in need. Most previous experience with patients infected by SARS, MERS, and H1N1 indicated that glucocorticoids delayed viral RNA clearance [53-55]. Nevertheless, one study on factors promoting the prolonged shedding of H1N1 indicated a significant association of viral clearance delay and delayed antiviral therapy, but not glucocorticoids treatment [56]. However, glucocorticoids treatment usually delayed antiviral therapy for two or more days after symptom onset and thus might have a more indirect role on the viral clearance delay [56]. Evidence is inconsistent on the viral clearance delay of glucocorticoid-treated COVID-19 patients. The most focus of the debate is the potential confounding role of doses and the severity of illness on the associations. Our meta-analysis pooled confounders-adjusted RRs and 


\begin{tabular}{|c|c|c|c|c|}
\hline Study & Size & $\begin{array}{l}\text { URR/aRR/ } \\
\text { MD }\end{array}$ & $95 \% \mathrm{Cl}$ & $\begin{array}{r}\text { Weight } \\
\%\end{array}$ \\
\hline Cao\&Zhu (a), 2021 & 72 & 0.89 & {$[0.42 ; 1.91]$} & 2.2 \\
\hline Cao\&Zhu (b), 2021 & 76 & 2.98 & {$[1.17 ; 7.57]$} & 1.8 \\
\hline Chang\&Zhao, 2020 & 67 & 1.25 & {$[1.12 ; 1.38]$} & 4.5 \\
\hline Cogliati-Dezza\&Oliva, 2021 & 179 & 1.60 & {$[1.51 ; 1.68]$} & 4.5 \\
\hline Feng\&Li, 2020 & 564 & 1.67 & {$[1.36 ; 2.05]$} & 4.2 \\
\hline Hu\&Li (a), 2020 & 148 & 1.33 & {$[1.28 ; 1.39]$} & 4.5 \\
\hline Hu\&Li (b), 2020 & 138 & 1.47 & {$[1.42 ; 1.53]$} & 4.6 \\
\hline Hu\&Yin, 2020 & 183 & 1.81 & {$[1.33 ; 2.46]$} & 3.9 \\
\hline Huang\&Zhu, 2020 & 309 & 1.55 & {$[1.19 ; 2.03]$} & 4.0 \\
\hline Jeronimo\&Farias, 2020 & 212 & 0.99 & {$[0.96 ; 1.02]$} & 4.6 \\
\hline Ji\&Zhang (a), 2020 & 684 & 1.11 & {$[1.10 ; 1.11]$} & 4.6 \\
\hline Ji\&Zhang (b), 2020 & 684 & 1.18 & {$[1.15 ; 1.21]$} & 4.6 \\
\hline Li\&Cao, 2020 & 66 & 2.08 & {$[1.88 ; 2.31]$} & 4.5 \\
\hline Lu\&Liu (a), 2021 & 374 & 1.21 & {$[1.12 ; 1.31]$} & 4.5 \\
\hline Lu\&Liu (b), 2021 & 203 & 0.46 & {$[0.38 ; 0.57]$} & 4.2 \\
\hline Lu\&Liu (c), 2021 & 171 & 2.85 & {$[2.39 ; 3.40]$} & 4.3 \\
\hline Masia\&Fernandez-Gonzalez, 2020 & 77 & 1.85 & {$[1.08 ; 3.18]$} & 3.0 \\
\hline Qi\&Yang, 2020 & 147 & 1.62 & {$[1.52 ; 1.72]$} & 4.5 \\
\hline Shi\&Wu, 2020 & 99 & 1.18 & {$[0.64 ; 2.17]$} & 2.7 \\
\hline Shu\&He, 2021 & 83 & 1.30 & {$[1.15 ; 1.48]$} & 4.4 \\
\hline Spagnuolo\&Guffanti (a), 2020 & 149 & 0.91 & {$[0.82 ; 1.01]$} & 4.5 \\
\hline Spagnuolo\&Guffanti (b), 2020 & 86 & 4.79 & {$[2.49 ; 9.22]$} & 2.6 \\
\hline Xu\&Chen, 2020 & 113 & 1.39 & {$[1.33 ; 1.45]$} & 4.5 \\
\hline Yan\&Liu, 2020 & 120 & 0.96 & {$[0.90 ; 1.03]$} & 4.5 \\
\hline Zuo\&Liu, 2020 & 181 & 1.21 & {$[0.87 ; 1.69]$} & 3.8 \\
\hline Total (random effect) & & 1.38 & {$[1.18 ; 1.61]$} & 100.0 \\
\hline
\end{tabular}

Heterogeneity: $I^{2}=98 \%, p<.001$

$[0.62 ; 3.06]$

Favours Favours

glucocorticoids control

Test for overall (random effect): $z=3.97(p<.001)$

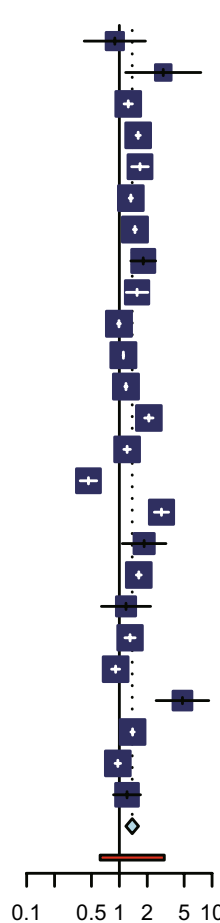

Unadjusted Risk Ratio (95\% Cl)

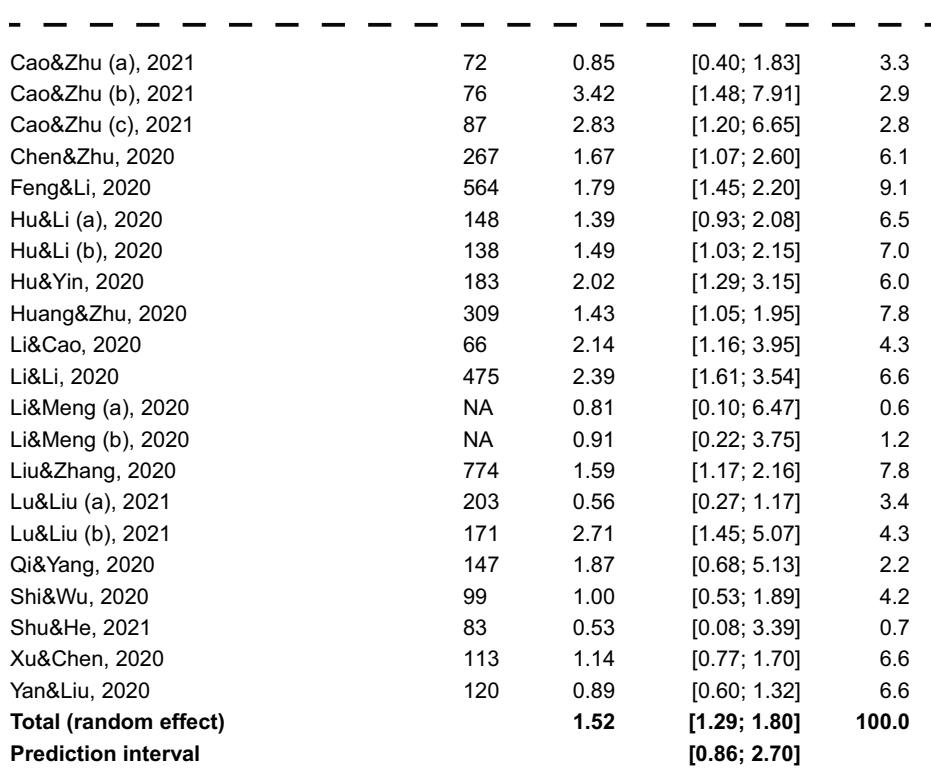

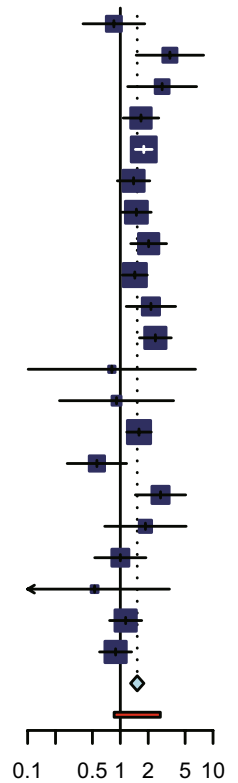

Test for overall (random effect): $z=4.94(p<.001)$

Fig. 2 Forest Plot for Risk of Viral Clearance Delay. The "(a), (b), or (c)" indicates one study with subgroups data was included in the analysis

conducted subgroup analyses by doses and the severity of illness. The findings of our meta-analysis of the association of glucocorticoids administration with delayed viral
RNA clearance were in line with the recently published results on COVID-19. We further discovered this 


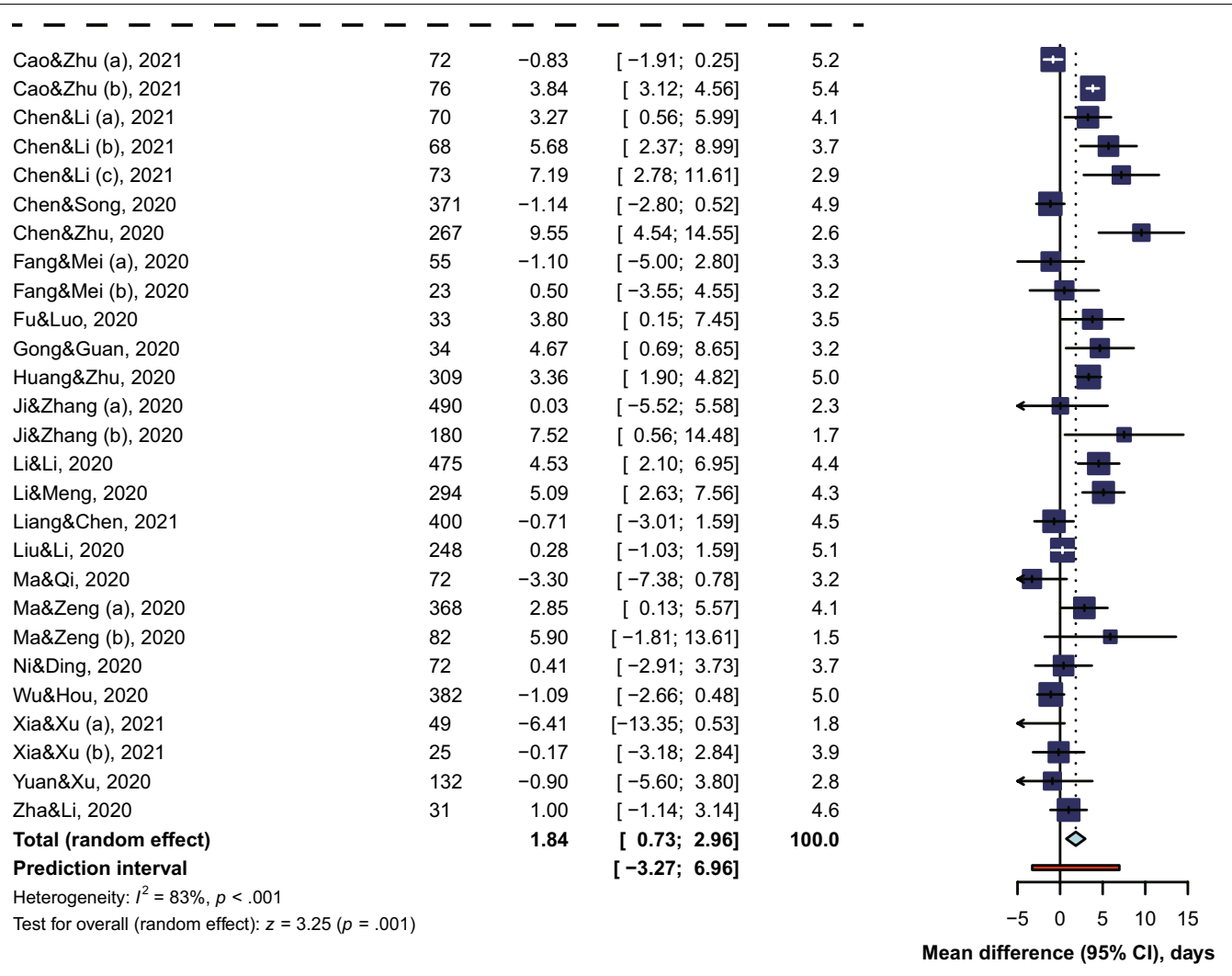

Fig. 2 continued

association occurred in patients receiving a high or a medium dose, but not a low dose of glucocorticoids.

\section{Strengths and limitations}

This systematic review and meta-analysis have several methodological strengths. We focused on the results of pooling adjusted RRs which could balance other potential confounders as possible. To exam the robustness of our main results, we conducted a series of presumable sensitivity analyses, in which extreme values were detected by influence analysis and then excluded by the leave-one-out method to avoid distortion of our pooled effect estimate. Moreover, we assessed potential high-risk subgroups by doses and the severity of illness, which was the main concern of glucocorticoids administration.

Our study has limitations. First, the results of this metaanalysis were main from observational studies and clinical heterogeneity was inevitable. Moreover, we failed to investigate the heterogeneity among studies that reported MDs due to limited data of confounders. Besides, the role of duration and types of glucocorticoids treatment on the viral clearance delay has not been further investigated due to insufficient accuracy of the information or lack of uniformity between studies. Moreover, most data came from China and whether the conclusion could be extended to other areas may be questionable. Finally, most of the reported data came from the early stage of the epidemic, and there were few reports on the data related to the mutated virus.

\section{Implications for practice}

Through, people who have a lot of experience with glucocorticoids in the treatment of inflammatory, little information could be obtained regarding its role in the humoral immune response against the virus. Many years ago, one trial involving 29 normal adult males showed that short courses ( 3 or 5 days) of high dose $(96 \mathrm{mg} / \mathrm{d})$ methylprednisolone could decrease serum IgG concentration [57]. Theoretically, the reduction in antibody production might delay viral clearance and experience a high risk of reinfection [40]. However, there was one study that demonstrated that dexamethasone treatment did not affect the formation of pneumococcal antibodies during community-acquired pneumonia [58]. Viral pneumonia should be different from bacterial pneumonia. Previous studies on H1N1, SARS, MERS have shown glucocorticoids' negative 
A

Subgroup

Size aRR

$95 \% \mathrm{Cl}$

Favours Favours

Weight

Mild or moderate

Feng\&Li, 2020

$\begin{array}{ll}495 & 1.69\end{array}$

[1.32; 2.17]

Li\&Li, 2020

$\begin{array}{ll}475 & 2.39\end{array}$

[1.61; 3.54]

Shu\&He, 2021

$83 \quad 0.53$

[0.08; 3.39]

Subtotal (random effect)

$[1.35 ; 2.57]$

Prediction interval

[0.09; 38.13]

Heterogeneity: $I^{2}=48 \%, p=.74$

Severe or critical

Feng\&Li, 2020

Li\&Meng (a), 2020

$\begin{array}{ll}69 & 1.85\end{array}$

$[1.05 ; 3.26]$

Li\&Meng (b), 2020

NA 0.81

$[0.10 ; 6.47]$

Liu\&Zhang, 2020

NA 0.91

[0.22; 3.75]

Subtotal (random effect)

$\begin{array}{ll}774 & 1.59\end{array}$

$[1.17 ; 2.16]$

Prediction interval

[1.23; 2.07]

Heterogeneity: $I^{2}=0 \%, p=.15$

Total (random effect)

$[0.90 ; 2.83]$

Prediction interval

$1.74 \quad[1.47 ; 2.04]$

[1.40; 2.15]

Heterogeneity: $I^{2}=0 \%, p=.45$

Test for overall (random effect): $z=6.63(p<.001)$

Test for between-subgroup-differences (random effect): $x_{1}^{2}=0.55, \mathrm{df}=1(p=.46)$

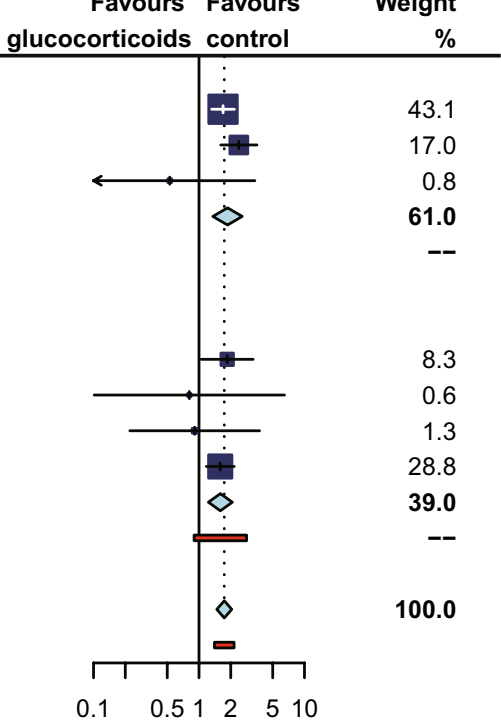

B

Subgroup

Size $\quad$ MD $\quad 95 \% \mathrm{Cl}$

Adjusted Risk Ratio (95\% Cl)

Mild or moderate

Ding\&Feng, 2020

Fang\&Mei, 2020

Fu\&Luo, 2020

Ji\&Zhang, 2020

Li\&Li, 2020

Liang\&Chen, 2021

Ma\&Zeng, 2020

Ni\&Ding, 2020

Xia\&Xu, 2021

$82 \quad 3.10 \quad$ [ $0.57 ; 5.63]$

$82 \quad 3.10 \quad[0.57 ; 5.63]$

$55 \quad-1.10 \quad[-5.00 ; 2.80]$

$33 \quad 3.80 \quad[0.15 ; 7.45]$

$\begin{array}{llr}490 & 0.03 & {[-5.52 ; 5.58]} \\ 475 & 4.53 & \text { [ } 2.10 ; 6.95]\end{array}$

$262-1.04 \quad[-3.65 ; 1.56]$

$\begin{array}{llr}368 & 2.85 & \text { [ } 0.13 ; 5.57] \\ 28 & 1.27 & {[-2.13 ; 4.67]}\end{array}$

$25 \quad-0.17 \quad[-3.18 ; 2.84]$

Subtotal (random effect)

1.67 [ $0.18 ; 3.16]$

[ $-2.53 ; 5.87]$

Prediction interval

Heterogeneity: $I^{2}=51 \%, p=.04$

Severe or critical

Chen\&Song, 2020

Fang\&Mei, 2020

$371 \quad-1.14 \quad[-2.80 ; 0.52]$

Ji\&Zhang, 2020

$23 \quad 0.50 \quad[-3.55 ; 4.55]$

Li\&Meng, 2020

$\begin{array}{lll}180 & 7.52 \quad[0.56 ; 14.48]\end{array}$

Liang\&Chen, 2021

Ma\&Qi, 2020

$294 \quad 5.09 \quad$ [ $2.63 ; 7.56]$

$96 \quad-3.63 \quad$ [ $-9.09 ; 1.82]$

Ma\&Zeng (b), 2020

$-3.30 \quad[-7.38 ; 0.78]$

$82 \quad 5.90 \quad[-1.81 ; 13.61]$

Wu\&Hou, 2020

$382-1.09 \quad[-2.66 ; 0.48]$

Xia\&Xu, 2021

$49-6.41 \quad[-13.35 ; 0.53]$

Subtotal (random effect)

0.17 [ $-2.17 ; 2.51]$

[ -7.08; 7.42]

Heterogeneity: $I^{2}=77 \%, p<.001$

Total (random effect)

$0.95 \quad[-0.45 ; 2.35]$

Prediction interval

[-4.33; 6.23]

Heterogeneity: $I^{2}=71 \%, p<.001$

Test for overall (random effect): $z=1.33(p=.19)$

Test for between-subgroup-differences (random effect): $x_{1}^{2}=1.12, \mathrm{df}=1(p=.29)$

Favours Favours Weight

\begin{tabular}{c|l} 
glucocorticoids & $\%$ \\
\hline & $\vdots$
\end{tabular}

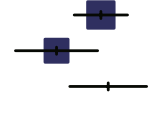

5.3

3.6

7.1

6.9

6.7

5.9

6.4

54.7

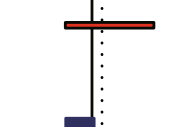

8.0

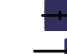

5.2
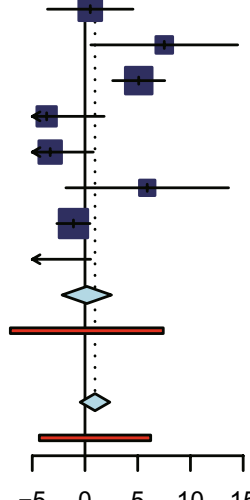

2.8

7.1

3.8

5.1

2.4

8.1

2.8

45.3

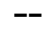

100.0

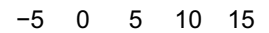

Mean difference $(95 \% \mathrm{Cl})$, days

Fig. 3 Subgroup Analysis by Severity of Illness 


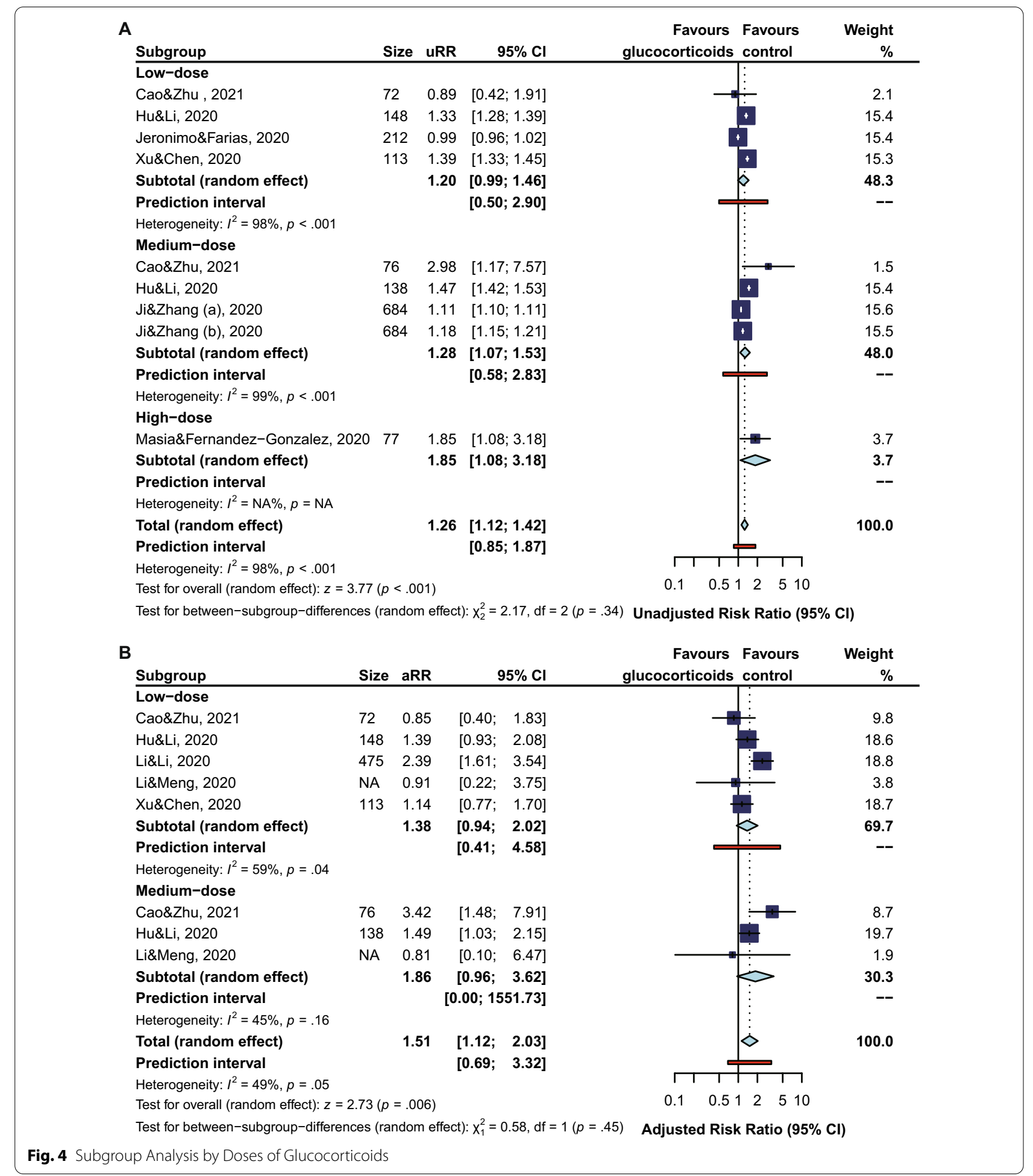

effects on viral clearance, however, the evidence is sporadic. We did the first meta-analysis to systematically investigate glucocorticoids' role on the viral clearance delay of SARS-CoV-2. Our conclusion indicated glucocorticoids might delay viral clearance in patients taking a high or medium dose, but not in patients taking a low dose. We believe our findings would further bring light to the current clinical practice in glucocorticoids 


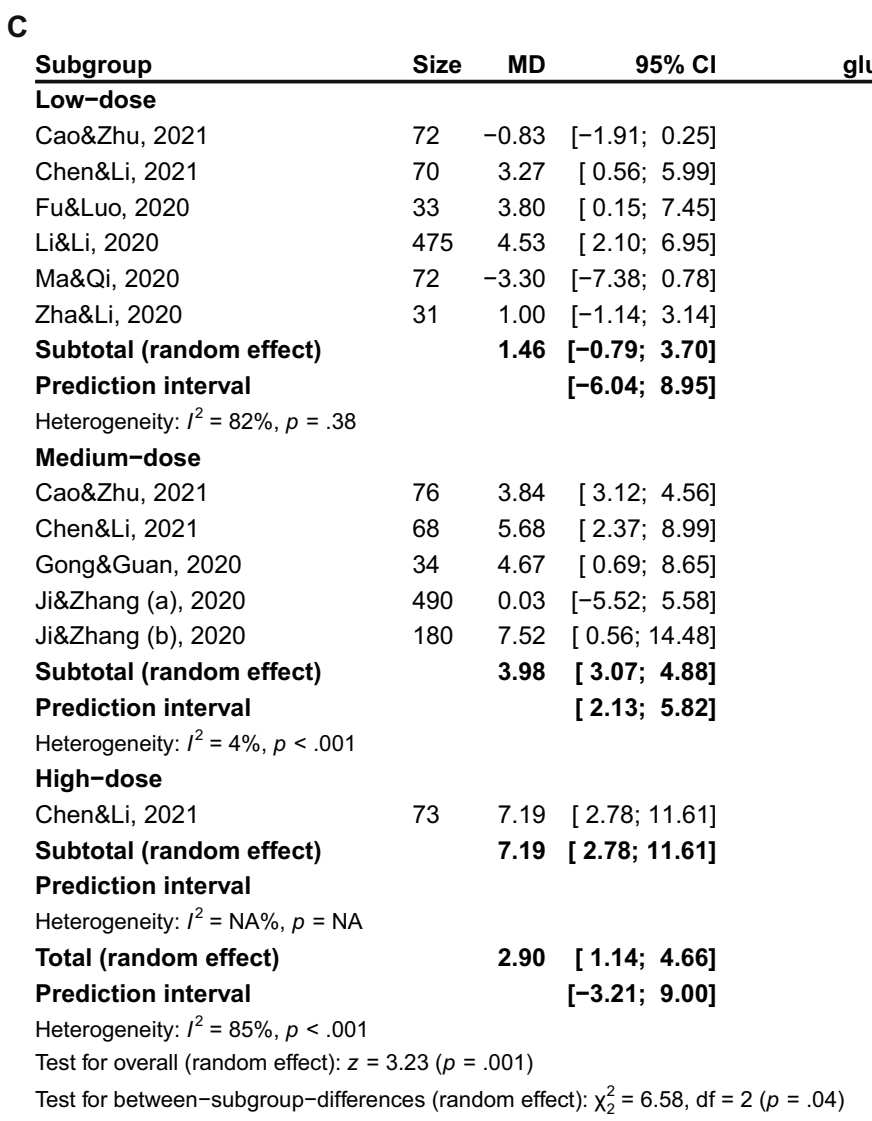

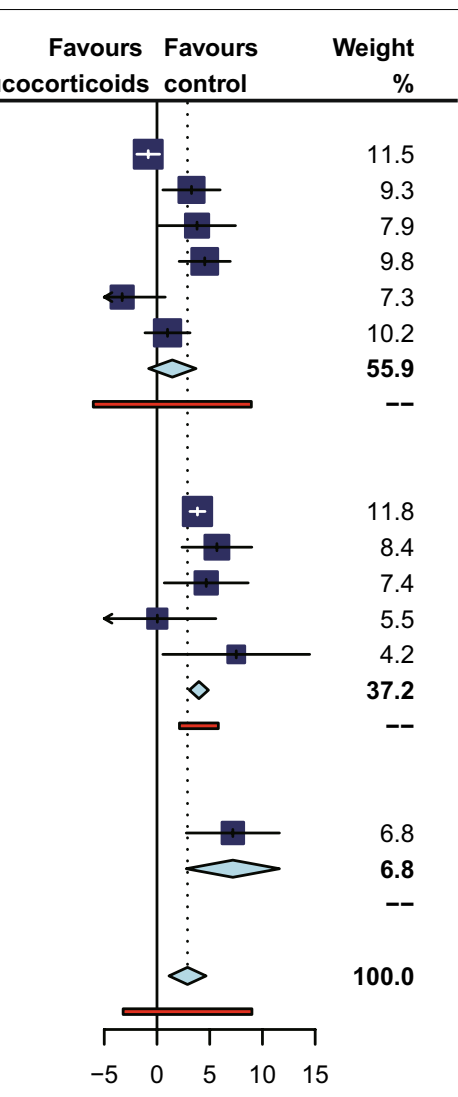

Mean difference $(95 \% \mathrm{Cl})$, days

Fig. 4 continued

treatment of COVID-19. Of note, one aspect worth further studying involves those with the hypercoagulable condition of high D-dimer level, as a concerning risk factor of COVID-19 death. The therapeutic effect of different treatment methods may be affected by the D-dimer level. Di Castelnuovo et al.. found heparin use was associated with lower in-hospital mortality in COVID-19 patients with D-dimer $>2020 \mathrm{ng} / \mathrm{mL}$ [59], whereas our previous meta-analysis indicated D-dimer seemed not to affect the associations between glucocorticoids treatment and mortality of COVID-19 patients [60]. Mondi et al.. reported D-dimer $>1000 \mathrm{ng} /$ $\mathrm{mL}$ at admission independently predicted prolonged SARS-CoV-2 RNA shedding [61]. However, whether the association between glucocorticoids treatment and viral clearance delay for COVID-19 patients is affected by $\mathrm{D}$-dimer level or not is still unclear. Moreover, other details of glucocorticoids treatment also need to be further explored in the future, such as the timing, duration, species, etc., and even the immune status of the population and the variation of the virus.

\section{Conclusions}

The findings suggest that glucocorticoids treatment delayed viral clearance in COVID-19 patients Moreover, it seems that patients taking a high dose or medium-dose rather than taking a low dose would experience a high risk of viral clearance delay.

\section{Abbreviations}

COVID-19: Coronavirus disease 2019; SARS: Severe acute respiratory syndrome; RCT: Randomized controlled trial; MOOSE: A proposal for reporting metaanalysis of observational studies in epidemiology; PRISMA: Preferred reporting items for systematic reviews and meta-analyses; NOS: Newcastle-OttawaScale; HRs: Hazard ratios; ORs: Odds ratios; RRs: Risk ratios; MD: Mean difference; Cl: Confidence interval; PI: Prediction interval.

\section{Supplementary Information}

The online version contains supplementary material available at https://doi. org/10.1186/s12879-021-06548-z.

Additional file 1: Table S1. Search Strategy.

Additional file 2: Table S2. Risk of Bias of Case-control Studies by the Newcastle-Ottawa-Scale (NOS) Assessment.

Additional file 3: Table S3. Risk of Bias of Retrospective Cohort Studies by the Newcastle-Ottawa-Scale (NOS) Assessment. 
Additional file 4: Table S4. Risk of Bias of the included RCT.

Additional file 5: Table S5. Adjusted Factors in Each Included Study.

Additional file 6: Figure S1. Sensitivity Analyses by Influence Analyses Based on Leave-one-out-method.

Additional file 7: Figure S2. Sensitivity Analyses by Excluding Studies of Case Control Design.

Additional file 8: Figure S3. Sensitivity Analyses by Excluding Studies of Retrospective Cohort Design

Additional file 9: Figure S4. Sensitivity Analyses by Excluding Studies with Non-low Risk of Bias.

Additional file 10: Figure S5. Funnel Plot of Unadjusted Risk Ratios for Risk of Viral Clearance Delay.

Additional file 11: Figure S6. Funnel Plot of Adjusted Risk Ratios for Risk of Viral Clearance Delay.

Additional file 12: Figure S7. Funnel Plot of Mean Differences for Risk of Viral Clearance Delay.

\section{Acknowledgements}

We thank Longhao Zhang (Chinese Evidence-based Medicine Centre, West China Hospital, Sichuan University) for his support in methodological suggestions for this meta-analysis.

\section{Authors' contributions}

$J B L, X L L, Z W Z$, and $Y K$ conceived the study and designed the protocol. JBL and $X L L$ performed the literature search. $H Y, W Z, Y Z$, and LPW selected the studies, exacted the relevant information, and assessed the risk of bias of included studies. JBL synthesized the data and wrote the first draft of the paper. All authors contributed to critically revising successive drafts and approved the final version. JBL, ZWZ, and YK are guarantors. The corresponding authors avouch that all listed authors meet authorship criteria and that no other qualified authors have been omitted. All authors read and approved the final manuscript.

\section{Funding}

This work is supported by Sichuan Science and Technology Programs (2021YFS0003 and 2021YJ0448) and the Project of Novel Coronavirus Pneumonia in West China Hospital (HX2019nCoV027). The study's funders had no role in the design and conduct of the study, data collection, data analysis, data interpretation, or writing of the report.

\section{Availability of data and materials}

Additional data are available from the corresponding author on reasonable request at kangyan@scu.edu.cn.

\section{Declarations}

\section{Ethics approval and consent to participate}

Not applicable.

\section{Consent for publication}

Not applicable.

\section{Competing interests}

All the authors declared no competing interests.

\section{Author details}

'Department of Critical Care Medicine, West China Hospital, Sichuan University, 37 Guo Xue Xiang St, Chengdu 610041, Sichuan, China. ${ }^{2}$ Molecular Medicine Research Center, State Key Laboratory of Biotherapy/Collaborative Innovation Center for Biotherapy, West China Hospital, Sichuan University, 37 Guo Xue Xiang St, Chengdu 610041, Sichuan, China.

Received: 4 March 2021 Accepted: 6 Auqust 2021 Published online: 14 October 2021

\section{References}

1. WHO. WHO Coronavirus Disease (COVID-19) Dashboard. https://covid19. who.int/. Accessed 4 Aug 2021.

2. Horby P, Lim WS, Emberson JR, et al.. Dexamethasone in hospitalized patients with Covid-19 - Preliminary report. N Engl J Med. 2020.

3. W. H. O. Rapid Evidence Appraisal for COVID-19 Therapies Working Group. Association between administration of systemic corticosteroids and mortality among critically ill patients with COVID-19: a meta-analysis. JAMA; 2020

4. Stroup DF, Berlin JA, Morton SC, et al. Meta-analysis of observational studies in epidemiology: a proposal for reporting. JAMA. 2000;283(15):2008-12.

5. Moher D, Liberati A, Tetzlaff J, Altman DG, PRISMA Group. Preferred reporting items for systematic reviews and meta-analyses: the PRISMA statement. BMJ. 2009;339(7716):b2535.

6. Cogliati-Dezza F, Oliva A, Cancelli F, et al. Determinants of prolonged viral RNA shedding in hospitalized patients with SARS-CoV-2 infection. Diagn Microbiol Infect Dis. 2021:100(2):115347.

7. Feng ZC, Li J, Yao SH, et al. Clinical factors associated with progression and prolonged viral shedding in COVID-19 patients: a multicenter study. Aging Dis. 2020;11(5):1069-81.

8. Yan D, Liu XY, Zhu YN, et al. Factors associated with prolonged viral shedding and impact of lopinavir/ritonavir treatment in hospitalised non-critically ill patients with SARS-CoV-2 infection. Eur Resp J. 2020;56(1):2000799.

9. Yuan ML, Xu XX, Xia DP, et al. Effects of corticosteroid treatment for nonsevere COVID-19 pneumonia: a propensity score-based analysis. Shock. 2020;54(5):638-43.

10. Chen XD, Zhu BY, Hong WX, et al. Associations of clinical characteristics and treatment regimens with viral RNA shedding duration in patients with COVID-19. Int J Infect Dis. 2020:98:252-60.

11. Hu ZG, Li SJ, Yang AL, et al. Delayed hospital admission and highdose corticosteroids potentially prolong SARS-CoV-2 RNA detection duration of patients with COVID-19. Eur J Clin Microbiol Infect Dis. 2021:40(4):841-8

12. Huang R, Zhu CW, Wang J, et al. Corticosteroid therapy is associated with the delay of SARS-CoV-2 clearance in COVID-19 patients. Eur J Pharmacol. 2020;889:173556.

13. Li Q, Li WX, Jin YP, et al. Efficacy evaluation of early, low-dose, short-term corticosteroids in adults hospitalized with non-severe COVID-19 pneumonia: a retrospective cohort study. Infect Dis Therapy. 2020;9:823.

14. Wells G, Shea B, O'Connell D, et al.. The Newcastle-Ottawa Scale (NOS) for assessing the quality if nonrandomized studies in meta-analyses. http:// www.ohri.ca/programs/clinical_epidemiology/oxford.htm. Accessed 3 April 2020.

15. IntHout J, loannidis JPA, Rovers MM, Goeman JJ. Plea for routinely presenting prediction intervals in meta-analysis. BMJ Open. 2016;6(7):e010247.

16. Spruance SL, Reid JE, Grace M, Samore M. Hazard ratio in clinical trials Antimicrob Agents Chemother. 2004;48(8):2787-92.

17. Zhang J, Yu KF. What's the relative risk? a method of correcting the odds ratio in cohort studies of common outcomes. JAMA. 1998:280(19):1690-1.

18. National Health Commission. Chinese clinical guidance for COVID-19 pneumonia diagnosis and treatment (7th edition). http://kjfymeetin gchina.org/msite/news/show/cn/3337.htm. Accessed 15 May 2020.

19. Peng FJ, Tu L, Yang YS, et al. Management and treatment of COVID-19: the Chinese experience. Can J Cardiol. 2020;36(6):915-30.

20. Viechtbauer W, Cheung MW. Outlier and influence diagnostics for metaanalysis. Res Synth Meth. 2010;1(2):112-25.

21. Cao HR, Zhu XY, Zhou $L$, et al. Factors associated with delayed viral shedding in COVID-19 infected patients: a retrospective small-scale study. Resp Med. 2021;178:106328

22. Chang D, Zhao $P$, Zhang DW, et al. Persistent viral presence determines the clinical course of the disease in COVID-19. J Allergy Clin Immunol Pract. 2020;8(8):2585.

23. Chen $\mathrm{Q}$, Song $Y$, Wang $\mathrm{L}$, et al. Corticosteroids treatment in severe patients with COVID-19: a propensity score matching study. Expert Rev Resp Med. 2020.

24. Chen YF, Li LJ. Influence of corticosteroid dose on viral shedding duration in patients with COVID-19. Clin Infect Dis. 2021;72(7):1298-1300. 
25. Ding C, Feng XW, Chen YF, et al. Effect of corticosteroid therapy on the duration of SARS-COV-2 clearance in patients with mild COVID-19: a retrospective cohort study. Infect Dis Therapy. 2020;9(4):943-52.

26. Fang XW, Mei Q, Yang TJ, et al. Low-dose corticosteroid therapy does not delay viral clearance in patients with COVID-19. J Infect. 2020;81(1):147-9.

27. Fu HY, Luo Y, Gao JP, et al. Effects of short-term low-dose glucocorticoids for patients with mild COVID-19. BioMed Res Int. 2020:2854186.

28. Gong Y, Guan L, Jin Z, Chen SX, Xiang GM, Gao BA. Effects of methylprednisolone use on viral genomic nucleic acid negative conversion and CT imaging lesion absorption in COVID-19 patients under 50 years old. J Med Virol. 2020;92(11):2551-5.

29. Hu FY, Yin G, Chen YP, et al. Corticosteroid, oseltamivir, and delayed admission are independent risk factors for prolonged viral shedding in patients with coronavirus disease 2019. Clin Resp J. 2020;14(11):1067-75.

30. Jeronimo CMP, Farias MEL, Val FFA, et al. Methylprednisolone as adjunctive therapy for patients hospitalized with COVID-19 (Metcovid): a randomised, double-blind, phase IIb, placebo-controlled trial. Clin Infect Dis. 2020;72(9):e373-81.

31. Ji JJ, Zhang JX, Shao ZY, Xie QF, Zhong L, Liu ZF. Glucocorticoid therapy does not delay viral clearance in COVID-19 patients. Crit Care. 2020;24(1):565

32. LiTZ, Cao ZH, Chen Y, et al. Duration of SARS-CoV-2 RNA shedding and factors associated with prolonged viral shedding in patients with COVID19. J Med Virol. 2020:93:506

33. Li YM, Meng QH, Rao X, et al. Corticosteroid therapy in critically ill patients with COVID-19: a multicenter, retrospective study. Crit Care 2020;24(1):698-707.

34. Liang MY, Chen P, He M, et al. Corticosteroids treatment of patients with coronavirus disease 2019: a propensity score matching study. Curr Med Sci. 2021;41(1):24-30.

35. Liu J, Zhang S, Dong $X$, et al. Corticosteroid treatment in severe COVID19 patients with acute respiratory distress syndrome. J Clin Investig. 2020;130(12):6417-28.

36. Liu ZB, Li X, Fan GH, et al. Low-to-moderate dose corticosteroids treatment in hospitalized adults with COVID-19. Clin Microbiol Infect. 2020;27(1):112-7.

37. Lu YY, Liu F, Tong GL, et al. Clinical evidence of an interferon-glucocorticoid therapeutic synergy in COVID-19. Signal Transduct Target Ther. 2021;6(1):107-17.

38. Ma Q, Qi D, Deng XY, et al. Corticosteroid therapy for patients with severe novel coronavirus disease 2019. Eur Rev Med Pharmacol Sci. 2020;24(15):8194-201

39. Ma YM, Zeng HH, Zhan ZJ, et al. Corticosteroid use in the treatment of COVID-19: a multicenter retrospective study in Hunan, China. Front Pharmacol. 2020;11:1198.

40. Masia M, Fernandez-Gonzalez M, Garcia JA, Padilla S, Gutierrez F. Lack of detrimental effect of corticosteroids on antibody responses to SARSCoV-2 and viral clearance in patients hospitalized with COVID-19. J Infect. 2020;82(3):414-51.

41. Ni Q, Ding C, Li YT, et al. Effect of low-to-moderate dose glucocorticoids on viral clearance in COVID-19: a retrospective study. Chin J Clin Infect Dis. 2020;13(1):21-4

42. Qi L, Yang $Y$, Jiang DX, et al. Factors associated with the duration of viral shedding in adults with COVID-19 outside of Wuhan, China: a retrospective cohort study. Int J Infect Dis. 2020;96:531-7.

43. Shi D, Wu WR, Wang Q, et al. Clinical characteristics and factors associated with long-term viral excretion in patients with SARS-CoV-2 infection: a single center 28-day study. J Infect Dis. 2020;222(6):910-8.

44. Shu HM, He S, Sun Y, et al. Factors influencing viral clearance in mild COVID-19 and clinical characteristics of asymptomatic patients. Biomed Res Int. 2021;2021:5909612.
45. Spagnuolo V, Guffanti M, Galli L, et al. Viral clearance after early corticosteroid treatment in patients with moderate or severe covid-19. Sci Rep. 2020;10(1):21291.

46. Wu CM, Hou DN, Du CL, et al. Corticosteroid therapy for coronavirus disease 2019-related acute respiratory distress syndrome: a cohort study with propensity score analysis. Crit Care. 2020;24(1):643.

47. Xia Q, Xu KJ, Ni Q, et al. Clinical efficacy of methylprednisolone and the combined use of lopinavir/ritonavir with arbidol in treatment of coronavirus disease 2019. J Med Virol. 2021:93(7):4446-53.

48. Xu KJ, Chen YF, Yuan J, et al. Factors associated with prolonged viral RNA shedding in patients with COVID-19. Clin Infect Dis. 2020;71(15):799-806.

49. Zha L, Li SR, Pan LL, et al. Corticosteroid treatment of patients with coronavirus disease 2019 (COVID-19). Med J Aust. 2020;212(9):416-20.

50. Zuo Y, Liu YL, Zhong Q, Zhang K, Xu YH, Wang ZX. Lopinavir/ritonavir and interferon combination therapy may help shorten the duration of viral shedding in patients with COVID-19: a retrospective study in two designated hospitals in Anhui, China. J Med Virol. 2020;92(11):2666-74.

51. Xiong LQ, Jin W, Hu XM, et al. Effect of glucocorticoid therapy on the prognosis of patients with severe and critical COVID-19: a singlecenter retrospective cohort study. Eur Rev Med Pharmacol Sci. 2021;25(2):1070-9.

52. Yousefifard M, Mohamed Ali K, Aghaei A, et al. Corticosteroids on the management of coronavirus disease 2019 (COVID-19): a systemic review and meta-Analysis. Iran J Public Health. 2020;49(8):1411-21.

53. Arabi YM, Mandourah Y, Al-Hameed F, et al. Corticosteroid therapy for critically ill patients with middle east respiratory syndrome. Am J Respir Crit Care Med. 2018;197(6):757-67.

54. Cao B, Gao H, Zhou B, et al. Adjuvant corticosteroid treatment in adults with influenza A (H7N9) viral pneumonia. Crit Care Med. 2016;44(6):e318-28

55. Lee N, Chan K, Hui DS, et al. Effects of early corticosteroid treatment on plasma SARS-associated coronavirus RNA concentrations in adult patients. J Clin Virol. 2004;31(4):304-9.

56. Ryoo SM, Kim WY, Sohn CH, et al. Factors promoting the prolonged shedding of the pandemic (H1N1) 2009 influenza virus in patients treated with oseltamivir for 5 days. Influenza Other Respir Viruses. 2013;7(5):833-7.

57. Butler WT, Rossen RD. Effects of corticosteroids on immunity in man. I. Decreased serum IgG concentration caused by 3 or 5 days of high doses of methylprednisolone. J Clin Invest. 1973;52(10):2629-40.

58. Van Mens SP, Meijvis SC, Grutters JC, Vlaminckx BJ, Bos WJ, Rijkers GT. Dexamethasone treatment has no effect on the formation of pneumococcal antibodies during community-acquired pneumonia. Clin Vaccine Immunol. 2012;19(5):811-3.

59. Di Castelnuovo A, Costanzo S, Antinori A, et al. Heparin in COVID-19 patients is associated with reduced in-hospital mortality: the multicenter italian CORIST study. Thromb Haemost. 2021;121(8):1054-65.

60. Li J, Liao X, Zhou Y, et al. Comparison of associations between glucocorticoids treatment and mortality in COVID-19 patients and SARS patients: a systematic review and meta-analysis. Shock. 2021;56(2):215-28.

61. Mondi A, Lorenzini P, Castilletti $\mathrm{C}$, et al. Risk and predictive factors of prolonged viral RNA shedding in upper respiratory specimens in a large cohort of COVID-19 patients admitted to an Italian reference hospital. Int J Infect Dis. 2021;105:532-9.

\section{Publisher's Note}

Springer Nature remains neutral with regard to jurisdictional claims in published maps and institutional affiliations. 